\title{
sensors
}

ISSN 1424-8220

(C) 2007 by MDPI

www.mdpi.org/sensors

Full Research Paper

\section{Biochemical Markers for Assessing Aquatic Contamination}

\author{
Marcela Havelková ${ }^{1, *}$, Tomáš Randák ${ }^{2}$, Vladimír Žlábek ${ }^{2}$, Jan Krijt $^{3}$, Hana Kroupová ${ }^{2}$, \\ Jana Pulkrabová ${ }^{4}$ and Zdeňka Svobodová ${ }^{1,2}$
}

1 University of Veterinary and Pharmaceutical Sciences Brno, Faculty of Veterinary Hygiene and Ecology, Palackeho 1-3, 61242 Brno, Czech Republic

2 University of South Bohemia Ceske Budejovice, Research Institute of Fish Culture and Hydrobiology Vodňany, Zatisi 728/II, 38925 Vodňany, Czech Republic

3 Charles University, First Faculty of Medicine, Institute of Pathological Physiology, U Nemocnice 5, 12853 Praha 2, Czech Republic

4 Institute of Chemical Technology Prague, Department of Food Chemistry and Analysis, Technicka

3, 16628 Praha 6, Czech Republic

* Author to whom correspondence should be addressed. E-mail: mhavelkova@vfu.cz

Received: 18 September 2007 / Accepted: 1 November 2007 / Published: 2 November 2007

\begin{abstract}
Biochemical markers, specifically enzymes of the first phase of xenobiotic transformation - cytochrome P450 and ethoxyresorufin-O-deethylase (EROD) - were used to determine the quantities of persistent organic pollutants (POPs) in fish muscle (PCB, $\mathrm{HCB}, \mathrm{HCH}, \mathrm{OCS}, \mathrm{DDT}$ ). Eight rivers were monitored (Orlice, Chrudimka, Cidlina, Jizera, Vltava, Ohře and Bílina; and the River Blanice was used as a control). The indicator species selected was the chub (Leuciscus cephalus L.). There were no significant differences in cytochrome P450 content between the locations monitored. The highest concentration of cytochrome $\mathrm{P} 450$ in fish liver was in the Vltava $\left(0.241 \mathrm{nmol} \mathrm{mg}^{-1}\right.$ protein), and the lowest was in the Orlice $\left(0.120 \mathrm{nmol} \mathrm{\textrm {mg } ^ { - 1 }}\right.$ protein). Analysis of EROD activity showed a significant difference between the Blanice and the Vltava $(\mathrm{P}<0.05)$, and also between the Orlice and the Vltava $(\mathrm{P}<0.01)$, the Orlice and the Bílina $(\mathrm{P}<0.01)$, and the Orlice and the Ohře $(\mathrm{P}<0.05)$. The highest EROD activity in fish liver was in the Vltava $\left(576.4 \mathrm{pmol} \mathrm{min}^{-1}\right.$ $\mathrm{mg}^{-1}$ protein), and the lowest was in the Orlice (63.05 pmol $\mathrm{min}^{-1} \mathrm{mg}^{-1}$ protein). In individual locations, results of chemical monitoring and values of biochemical markers were compared. A significant correlation $(\mathrm{P}<0.05)$ was found between biochemical markers and OCS, and PCB. Among the tributaries studied those that contaminated the Elbe most were the Vltava and the Bílina. These tributaries should not be considered the main sources of industrial contamination of the River Elbe, because the most important contamination sources were along the river Elbe itself.
\end{abstract}


Keywords: cytochrome P450, EROD, Leuciscus cephalus L., persistent organic pollutants, River Elbe

\section{Introduction}

The dramatic increase in anthropogenic activity since the early $20^{\text {th }}$ century has had a negative impact on all parts of the environment. The aquatic environment has become an easily accessible disposal site for xenobiotics and pollutants such as organochlorine compounds - PCBs and chlorinated pesticides. Contamination of water with industrial and agricultural pollutants influences the biochemical processes of aquatic organisms. An effective monitoring system using biochemical markers has been established to demonstrate these xenobiotics in the environment. The cytochrome P450 system has proved to be a very suitable tool for biochemical and environmental monitoring [1]. Suitable markers have been used to assess contamination in the River Elbe, which is ranked among the very important European aquatic ecosystems. The river is $1103.5 \mathrm{~km}$ long and its catchment covers $148268 \mathrm{~km}^{2}$. The river flows through two countries, the Czech Republic $\left(51336 \mathrm{~km}^{2}\right)$ and Germany (96932 $\mathrm{km}^{2}$ ). Contamination remains a focus of attention [2-7].

A project of intensive research into contamination of the River Elbe, called Projekt Labe I (19911994), was launched in 1991. At present, Projekt Labe IV is in progress, and is centred on potential sources of the river's contamination, that is on the important tributaries. These were the Orlice, Chrudimka, Cidlina, Jizera, Vltava, Ohře and Bílina. The River Blanice was used as a control.

The indicator species selected was the chub (Leuciscus cephalus L.). Fish were caught at sites along the lower reaches of the tributaries and upstream of the first migration barrier before their discharge to the Elbe. The effect of contamination on fish populations was assessed using biochemical markers (specifically enzymes of the first stage of xenobiotic conversion, namely cytochrome P450 and ethoxyresorufin-O-deethylase) and chemical analyses of fish muscle tissue.

Cytochrome P450 (CYP 450) is an important biochemical marker and indicator of contamination with some pollutants [8]. It is particularly sensitive to a broad spectrum of industrial contaminants (e.g. dioxins, polychlorinated biphenyls - PCB, polycyclic aromatic hydrocarbons - PAH) [9,10]. These pollutants accumulate in large quantities in river sediments [11], and from there they get in aquatic organisms via the food chain. The most important indicator of aquatic environment contamination seems to be subfamily $1 \mathrm{~A}$ of cytochrome P450 [12].

Another enzyme, ethoxyresorufin-O-deethylase (EROD) is functionally linked to cytochrome P450. This enzyme transforms substrates into products emitting a measurable fluorescent signal and is more sensitive than the determination of CYP 450. EROD enzyme activity was also determined as part of aquatic environment contamination monitoring $[4,5,13,14]$.

The aim of the study was to assess the degree of contamination in selected tributaries of the Elbe, using biochemical markers in male chub; to compare results of biochemical and chemical monitoring; and to assess the relationship between CYP 450 and EROD. 


\section{Methods}

In summer (from May to June) 2006, male chub were caught in the Orlice (992 km river's length), the Chrudimka (967 km river's length), the Cidlina (907 km river's length), the Jizera (868 km river's length), the Vltava (837 km river's length), the Ohře (792 km river's length), and the Bílina (765 km river's length), and at a location on the control River Blanice. These individual locations are shown in Figure 1.

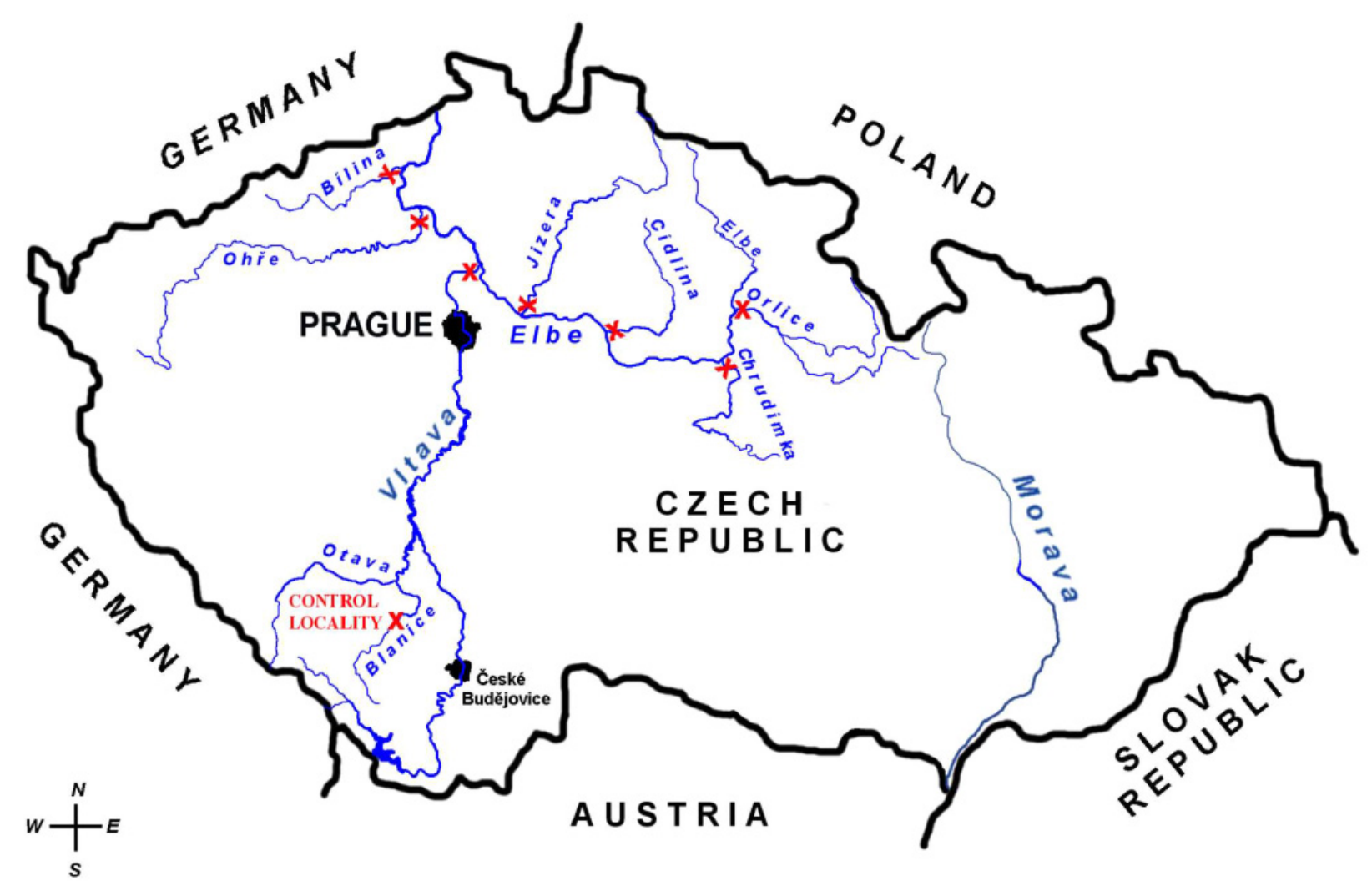

Figure 1. Map of the Czech Republic and location of sampling sites and the control site.

At each location, 3-10 chub were caught. The biometric characteristics of these fish are given in Table 1. The fish were killed, measured, weighed, aged from scales, and their health status determined by macroscopic examination. Individual liver samples were taken for analysis of biochemical markers (cytochrome P450, EROD) and individual muscle samples for POPs (PCB, DDT, HCB, HCH, OCS) concentrations. Immediately after collection, liver samples were placed in cryotubes into liquid nitrogen and stored at $-86^{\circ} \mathrm{C}$, where they were kept until use. Muscle samples were stored at $-20^{\circ} \mathrm{C}$. 
Table 1. Biometric characteristics of male chub (Leuciscus cephalus L.), $\mathrm{n}=$ number of fish examined.

\begin{tabular}{llll}
\hline Location & (n) & $\begin{array}{l}\text { Weight (g) } \\
\text { mean } \pm \boldsymbol{S D}\end{array}$ & $\begin{array}{l}\text { Age (years) (mean of the total) } \\
\text { (min-max) }\end{array}$ \\
\hline ORLICE & 6 & $323 \pm 39$ & $3.8(3-4)$ \\
CHRUDIMKA & 10 & $180 \pm 11$ & $3.2(3-4)$ \\
CIDLINA & 9 & $238 \pm 53$ & $3.7(2-5)$ \\
JIZERA & 3 & $377 \pm 189$ & $4.0(3-5)$ \\
VLTAVA & 7 & $290 \pm 30$ & $3.3(3-4)$ \\
OHŘE & 10 & $541 \pm 64$ & $4.8(3-7)$ \\
BÍLINA & 10 & $121 \pm 18$ & $2.3(2-3)$ \\
BLANICE (control location) & 10 & $339 \pm 39$ & $4.8(3-6)$ \\
\hline
\end{tabular}

\subsection{Liver sample processing}

Liver samples were homogenized in homogenizing buffer $(0.25 \mathrm{M}$ saccharose, $0.01 \mathrm{M}$ TRIS and $0.1 \mathrm{mM}$ EDTA). Processed samples were then poured into centrifugation test tubes and centrifuged at $10000 \mathrm{~g}$ for $20 \mathrm{~min}$ at $4^{\circ} \mathrm{C}$. The supernatant was carefully pipetted to ultracentrifugation tubes and centrifuged again at $100000 \mathrm{~g}$ for $1 \mathrm{~h}$ at $4^{\circ} \mathrm{C}$. The supernatant was drained, pellets were washed with buffer and, then, resuspended in buffer. This suspension was put into individual eppendorf tubes and stored at $-80^{\circ} \mathrm{C}$ until use. Before the enzymes were assayed, microsomal protein concentrations were determined by the Lowry method [15].

\subsection{Quantitative determination of cytochrome P450}

Total cytochrome P450 was determined by visible light spectrophotometry at 400-490 nm wavelength range on the basis of the difference between absorbance readings at 450 and $490 \mathrm{~nm}$, and the values obtained were then transformed to final concentrations. Measurements were made after cytochrome reduction by sodium dithionite and after the complex with carbon oxide was formed. The method is described in detail in [5].

\subsection{EROD activity determination}

Activity of the enzyme ethoxyresorufin-O-deethylase (EROD) was measured by spectrofluorometry. The method is described in detail in [5]. In the presence of the enzyme, its activity transforms the substrate ethoxyresorufin to resurufin in the presence of NADPH. Measurements were made using the Perkin-Elmer Fluorescence Spectrophotometer 203.

\subsection{Determination of POPs in muscle samples}

Polychlorinated biphenyl (PCB) indicator congeners - IUPAC numbers 28, 52, 101, 118, 138, 153 and 180, hexachlorbenzene (HCB), $\alpha-, \beta-, \gamma$-isomers of hexachlorocyklohexane $(\mathrm{HCH})$, octachlorostyrene (OCS) and DDT and its degradation products DDD and DDE were determined in individual muscle samples by means of two-dimensional capillary gas chromatography (2D/HRGC) 
employing two parallel columns of equal dimension differing in selectivity (DB-5 and DB-17) and two electron-capture detectors (ECD). Isolation of target analytes from fish muscle was carried out by Soxhlet extraction into a hexane:dichloromethane $(1: 1, \mathrm{v} / \mathrm{v})$ solvent mixture. The clean-up of extracts was performed, as for alkylphenols, by GPC on a Bio-Beads S-X3 column and mobile phase ethylacetate:cyclohexane $(1: 1, \mathrm{v} / \mathrm{v})$. ). The method is described in detail in [16].

\subsection{Statistical methods}

Statistical analysis of the data was performed using the program STATISTICA 6.1 for Windows (StatSoft ČR). The data were assessed by non-parametric methods because data normality was not proven. The Kruskal-Wallis test was used to compare contamination levels of the exogenous substances monitored in individual profiles. The same test was used to compare biochemical markers of contamination between individual profiles. Whenever the Kruskal-Wallis test showed statistically significant differences between profiles $(\mathrm{P}<0.05)$, multiple comparisons of all profiles were subsequently performed. Relations between individual parameters were assessed using Spearman's correlation coefficient (R).

\section{Results}

\subsection{Macroscopic assessment of health status of fish}

The health status of the fish was examined before tissue samples were collected. Eye damage (exophthalmos and corneal opacity) was found in two fish from the Vltava. Pathological changes of the gonads (neoplasms and an atrophy of part of the gonads) were found in fish from the Cidlina (1 fish), the Orlice (2 fish) and the Ohře (1 fish). Macroscopic examination of chub from the Blanice and from the remaining locations revealed no pathological changes in the fish.

\subsection{Biochemical markers}

The highest cytochrome P450 concentrations in fish liver were in the Vltava $\left(0.241 \mathrm{nmol} \mathrm{mg}^{-1}\right.$ protein), while the lowest concentrations were in the Blanice $\left(0.152 \mathrm{nmol} \mathrm{mg}^{-1}\right.$ protein) and the Orlice $\left(0.120 \mathrm{nmol} \mathrm{mg}^{-1}\right.$ protein). Statistical analysis showed no significant differences in cytochrome P450 concentrations in the liver of indicator fish between locations.

The highest EROD activity in fish liver was in the Vltava (576.4 $\mathrm{pmol} \mathrm{min}^{-1} \cdot \mathrm{mg}^{-1}$ protein), and the lowest level was in the Orlice (63.05 pmol $\mathrm{min}^{-1} . \mathrm{mg}^{-1}$ protein) (Figure 2). The Blanice, which was the control, was $213.7 \mathrm{pmol} \mathrm{min}^{-1} . \mathrm{mg}^{-1}$ protein. Statistical analysis of EROD activity showed a significant difference $(\mathrm{P}<0.05)$ between the Blanice control and the Vltava, and also a significant difference between the Orlice and the Vltava $(\mathrm{P}<0.01)$, the Bílina $(\mathrm{P}<0.01)$ and the Ohře $(\mathrm{P}<0.05)$. 


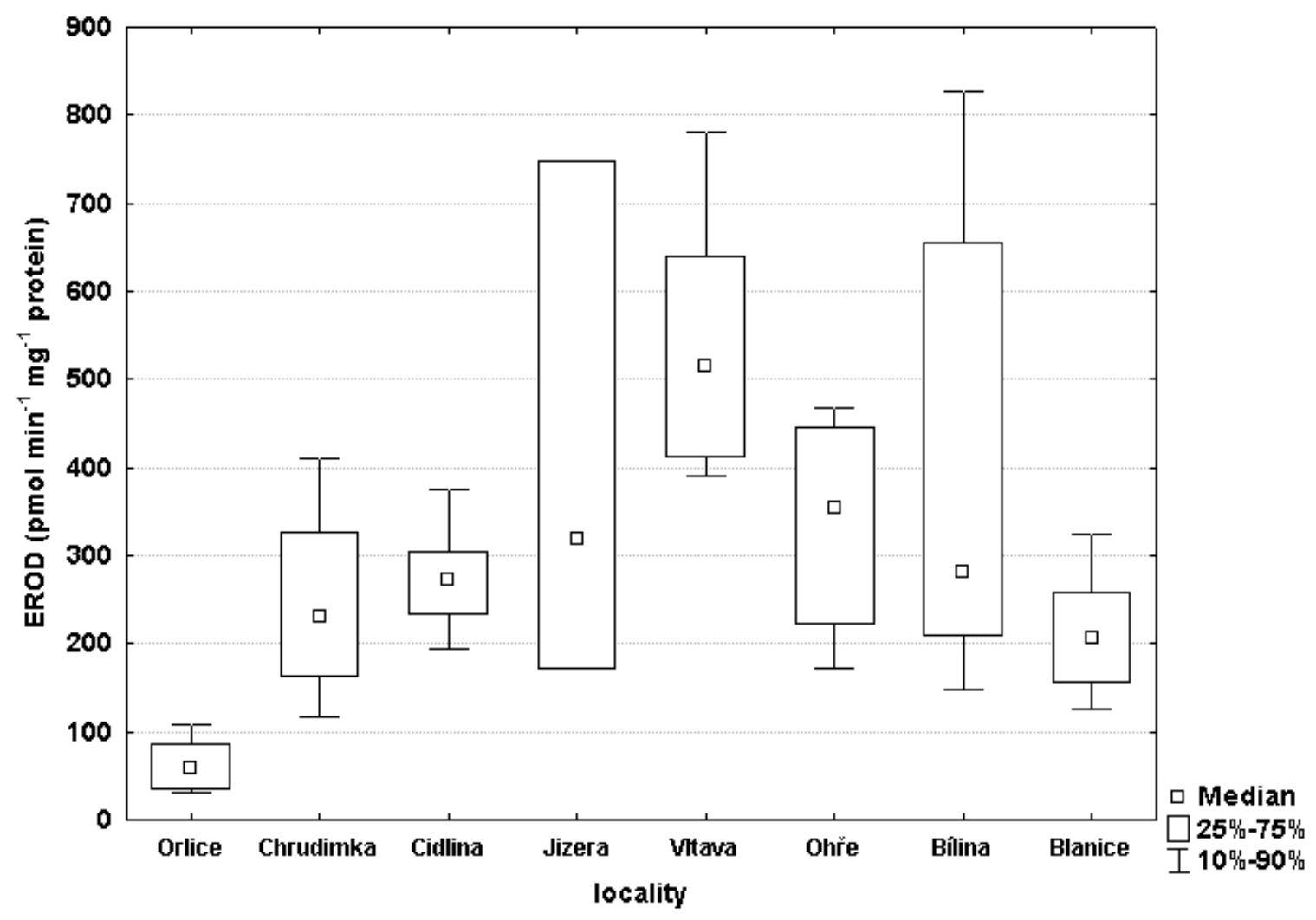

Figure 2. EROD activity in liver samples of male chub

Significant correlations $(\mathrm{R}=0.687)$ between EROD activity and cytochrome $\mathrm{P} 450$ were found in fish from all locations at $\mathrm{P}<0.01$.

Table 2. Content of persistent organic pollutants in male chub (Leuciscus cephalus L.) ( $\mu \mathrm{g} \mathrm{kg}^{-1}$ of muscle, w.w.).

\begin{tabular}{llllll}
\hline LOCATION & PCB* & DDT** & HCB & $\begin{array}{l}\text { HCH } \\
* * *\end{array}$ & OCS \\
\hline ORLICE & $15.1 \pm 2.66$ & $10.6 \pm 1.54$ & $1.51 \pm 0.23$ & $0.31 \pm 0.1$ & $0.028 \pm 0.004$ \\
CHRUDIMKA & $9.1 \pm 1.18$ & $13.0 \pm 1.27$ & $1.57 \pm 0.10$ & $0.22 \pm 0.04$ & $0.041 \pm 0.003$ \\
CIDLINA & $13.7 \pm 3.24$ & $8.1 \pm 1.67$ & $0.52 \pm 0.05$ & $0.45 \pm 0.10$ & $0.072 \pm 0.02$ \\
JIZERA & $51.9 \pm 23.73$ & $23.2 \pm 10.21$ & $1.22 \pm 0.36$ & $0.20 \pm 0.02$ & $0.24 \pm 0.13$ \\
VLTAVA & $46.1 \pm 7.11$ & $25.1 \pm 3.23$ & $1.55 \pm 0.19$ & $0.21 \pm 0.03$ & $0.12 \pm 0.02$ \\
OHŘE & $68.6 \pm 10.95$ & $44.0 \pm 5.51$ & $2.82 \pm 0.38$ & $0.56 \pm 0.21$ & $0.46 \pm 0.23$ \\
BÍLINA & $31.9 \pm 2.92$ & $14.4 \pm 1.73$ & $2.93 \pm 0.38$ & $0.32 \pm 0.01$ & $0.10 \pm 0.02$ \\
BLANICE (control location) & $10.8 \pm 1.06$ & $35.0 \pm 4.09$ & $1.75 \pm 0.20$ & $0.18 \pm 0.03$ & $0.03 \pm 0.008$ \\
\hline
\end{tabular}

* sum of 7 indicator congeners $(28,52,101,118,138,153,180)$; ** sum of DDT (o,p'- DDE; p, p'- DDE; o,p'- DDD; $\left.p, p^{\prime}-\mathrm{DDD} ; o, p^{\prime}-\mathrm{DDT} ; p, p^{\prime}-\mathrm{DDT}\right) ; * * *$ sum of $\mathrm{HCH}$ isomers $(\alpha, \beta, \gamma)$ 


\subsection{Chemical monitoring}

Results of chemical monitoring are summarized in Table 2 and Figure 3. The highest concentrations of pollutants monitored were in fish from the Ohře and the Vltava. The lowest concentrations were in the Blanice and in the Chrudimka.

PCB concentrations in muscle of indicator fish from the Ohře $(\mathrm{P}<0.01)$ and the Vltava $(\mathrm{P}<0.05)$ were significantly higher than those found in the fish from the Blanice. Significant differences were also found between the Chrudimka and the Vltava $(\mathrm{P}<0.01)$ and the Ohře $(\mathrm{P}<0.05)$, and between the Ohře and the Cidlina $(\mathrm{P}<0.05)$. Among all the indicator PCB congeners, the large majority $(70-80 \%)$ were the higher chlorinated PCB congeners 138, 153 and 180.

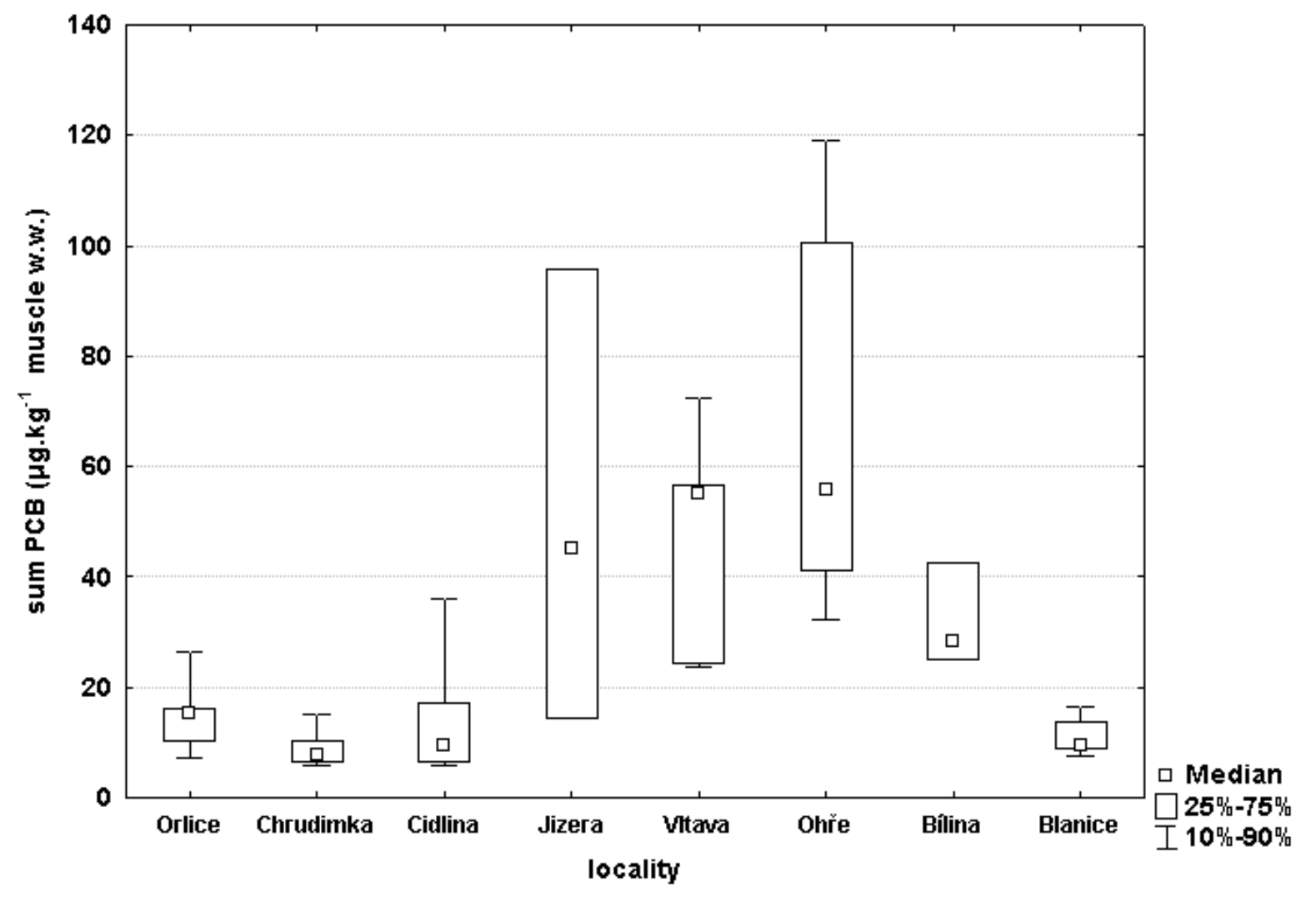

Figure 3. Content of PCB (sum of 7 indicator congeners) in male chub muscle samples (wet weight)

The lowest muscle DDT concentrations were in indicator fish from the Cidlina. The river with the highest DDT pollution was the Ohře (44.01 $\mu \mathrm{g} \mathrm{kg}^{-1}$ muscle). DDT muscle concentrations in the Orlice and the Cidlina were significantly lower $(\mathrm{P}<0.05)$ than those found in the Blanice. Significant $(\mathrm{P}<$ 0.01) differences were found between the Ohře and the Chrudimka, the Ohře and the Orlice, and the Ohře and the Cidlina.

The highest HCB muscle concentrations were in chub from the Ohře and the Bílina, the lowest in chub from the Cidlina. Concentration of $\mathrm{HCB}$ in fish muscle from the Cidlina were significantly lower than those in the Blanice $(\mathrm{P}<0.01)$, and in fish from the Chrudimka $(\mathrm{P}<0.05)$, the Ohře $(\mathrm{P}<0.01)$ and the Bílina $(\mathrm{P}<0.01)$. 
Statistical analysis showed no significant differences in $\mathrm{HCH}$ muscle concentrations between locations. The highest $\mathrm{HCH}$ concentrations in muscle of indicator fish were found in the Cidlina, and the lowest $\mathrm{HCH}$ concentrations were in the Blanice tributary. The most abundant were the $\beta$-isomer (35-50\%) and $\gamma$-isomer (i.e. lindane) (35-50\%), while the least abundant was the $\alpha$-HCH isomer (approx. $15 \%$ ).

The lowest OCS concentrations in muscle were found in the Blanice, the highest in the Ohře and the Jizera. OCS muscle concentrations in chub from the Ohře were significantly higher $(\mathrm{P}<0.05)$ than those from fish from the Blanice, the Orlice and the Chrudimka.

\subsection{Correlations between biochemical markers and pollutant concentrations}

Correlating results of chemical monitoring and the results of biochemical marker measurements revealed significant relationships $(\mathrm{P}<0.05)$ between cytochrome $\mathrm{P} 450$ concentrations and the concentrations of PCB $(\mathrm{R}=0.317)$ and $\mathrm{OCS}(\mathrm{R}=0.329)$ in muscle of indicator fish. A significant correlation $(\mathrm{P}<0.05)$ was also found between EROD activity and the concentrations of $\mathrm{PCB}(\mathrm{R}=0.396)$ and $\mathrm{OCS}(\mathrm{R}=0.436)$ in muscle of indicator fish.

\section{Discussion}

Biochemical monitoring showed that the most contaminated tributaries of the Elbe were the rivers Vltava, Ohře, Bílina and Jizera. EROD activity in the liver of chub ranged between $63.1 \mathrm{pmol} \mathrm{min}^{-1}$ $\mathrm{mg}^{-1}$ protein (the Orlice) and $576.4 \mathrm{pmol} \mathrm{min}^{-1} \mathrm{mg}^{-1}$ protein (the Vltava), cytochrome P450 concentrations were between $0.120 \mathrm{nmol} \mathrm{mg}^{-1}$ protein (the Orlice) and $0.241 \mathrm{nmol} \mathrm{mg}^{-1}$ protein (the Vltava). The broad range of EROD activity observed in fish from the sampling locations may be due to the typical induction of cytochrome P450, where small differences in levels of cytochrome inductor exposure will be translated into relatively large differences in enzymatic activity. Organisms exposed to the natural environment are affected by a number of biotic and abiotic factors, which sometimes result in considerable variations in cytochrome P450 values and EROD activity [17]. Substances responsible for the activation of biochemical markers were present in all the locations monitored. Biochemical markers reflect the exposure of the organism to pollutants in their environment and, because they are easy to measure, they are often used as aquatic environment contamination assessment indicators [14] - the river Mures in Rumania, [18] - contamination of rivers in southern Belgium,

[19] - Karnaphuly River in Bangladesh, [20] - small streams in an urban area. Biochemical markers for the assessment of the contamination of the River Elbe in the Czech Republic with organic pollutants have also been used by [4,5]. The highest values of EROD activity along the Elbe were reported by these authors from Valy (263.2 $\mathrm{pmol} \mathrm{min}^{-1} \mathrm{mg}^{-1}$ protein), a location negatively affected by the chemical industry. The least contaminated was the control site, the river Blanice. The highest cytochrome P450 concentration was recorded in Lysá nad Labem in the middle reaches of the Elbe $\left(0.48 \mathrm{nmol} \mathrm{mg}{ }^{-1}\right.$ protein). The assessment of organic pollutants contamination of the River Elbe on German territory using biochemical markers has been conducted by, e.g. [3,21-23] found higher values of biochemical markers (EROD and cytochrome system) at locations along the Elbe near the Czech Republic compared with locations situated further downstream. Cytochrome P450 values found at 
locations monitored in Germany are comparable with values ascertained in this study in the Czech Republic. Broeg et al. used EROD activity as one of several parameters they monitored when they assessed contamination in four locations [21]. They found the highest EROD activity levels in the Elbe estuary, indicating that the River Elbe is contaminated with xenobiotics along its entire length.

Biochemical markers are important indicators of organic pollutant contamination of the environment. Monitoring these markers showed differences in contamination levels in different locations. These differences were confirmed by the results of chemical monitoring. Results of biochemical monitoring indicated that the most contaminated tributaries were the rivers Jizera, Vltava, Ohře and Bílina. At the same time, correlation was demonstrated $(\mathrm{P}<0.05)$ between concentrations of biochemical markers and the amounts of chemical pollutants (specifically between cytochrome P450 and $\Sigma$ PCB, cytochrome P450 and OCS, EROD activity and $\Sigma$ PCB and EROD activity and OCS). PCB is one of important cytochrome P450 inductors. The most abundantly represented PCB congeners included higher chlorinated PCB congeners (Nos 138, 153 and 180). Higher chlorinated PCBs in the Elbe have also been reported in Germany where Heinisch et al. monitored PCB in fish and sediment along the entire river [24]. The frequent occurrence of higher chlorinated PCB congeners in the environment is the result of past use of technical mixes (e.g. Delor 106), which contain relatively high amounts of higher chlorinated congeners. In Czechoslovakia, 21482 tonnes of PCB were produced between 1959 and 1984, of which Delor 106 contributed about $20 \%$ (4 381 tonnes) [25].

The highest muscle concentrations of DDT were in fish from the Ohře, and the lowest were from the Cidlina. In all the samples examined, the dominant proportion in the sum of substances derived from DDT was made up of the isomer p,p'-DDE (75-90\%). Large amounts of the p,p'-DDE metabolite are suggestive of old contamination because the DDT to DDE conversion is relatively slow and, moreover, the parent substance DDT/DDE metabolite ratio is very low. p, $\mathrm{p}^{\prime}$-DDE isomer is the final product of metabolic transformation of the $\mathrm{p}, \mathrm{p}^{\prime}$-DDT insecticide. A role in this transformation, that takes place in the liver, is played by the P450 cytochrome system [26]. The levels of other substances decreased in the order: DDE $>>$ DDD $>>$ DDT. All tests showed only minimum quantities of o, $\mathrm{p}^{\prime}$ - isomers. o, $\mathrm{p}^{\prime}$-isomers are less stable than $\mathrm{p}, \mathrm{p}^{\prime}$-isomers and are therefore detected in low concentrations in the environment. The o, $\mathrm{p}^{\prime}$-DDT isomer has a mild oestrogenic activity [27,28]. Some DDT isomers can be classified as environmental endocrine disruptors because they may cause disruption of the endocrine system [29,30]. Bioaccumulation of DDT and its metabolites in the brain causes an induction of liver enzymes [31] and a disruption of hormonal mechanisms [32].

$\mathrm{HCB}$, another major environmental contaminant, used to be used as a fungicide for cereal seed. Nowadays it is brought into the environment as an intermediate product of a number of chlorinated compounds, particularly of lower chlorinated benzenes and of some pesticides [33]. Hexachlorobenzene is an omnipresent substance produced during combustion. The European parliament regulation 2000/60/EC identifies HCB as a priority hazardous substance. The main source of HCB for the Elbe's aquatic ecosystem is the waste site at Chabařovice, which is an abandoned brown coal open pit where municipal wastes and about 80000 barrels of HCB-containing chemical waste from chemical plants were dumped between 1978 and 1990. Chlorobenzenes in various locations along the River Elbe (in water and in the sediment) in the Czech Republic and in Germany were monitored by Heinisch et al. [34]. HCB in the Elbe was demonstrated in bream (Abramis brama) and eel (Anguilla anguilla) as early as the 1980s [35,36]. OCS and HCB are considered the main 
organochlorine contaminants of the Elbe. Marth et al. measured levels of chlorinated hydrocarbon contaminants (HCB, OCS, DDT and PCB) in muscle and liver of bream at various locations along the Elbe in Germany [37]. Higher levels of organochlorine pollutant contamination were found mainly in fish from locations in the upper reaches of the river.

The lowest OCS concentrations in muscle were in the Blanice tributary, the highest in the Ohře and the Jizera. These concentrations were, however, lower by two orders of magnitude than those reported by Bester et al. in the liver of bream in the Elbe in Germany [38]. Though octachlorostyrene is a pollutant that is known to be prevalent in the environment, there may be sources that are still emitting significant amounts of chlorostyrenes along the River Elbe. Generally, such industrial sources exhibit their own chemical profile in their emissions.

Of the three $\mathrm{HCH}$ isomers, the most abundantly represented were the $\beta$ isomer and $\gamma$-isomer. (i.e. lindane). Lindane, has been used frequently in agriculture for its insecticidal action, and is still found in the environment because of its bioaccumulation in soil. Investigating bream from locations along the Elbe in Germany, Marth et al. found that the most abundant $\mathrm{HCH}$ isomers were a-HCH and b-HCH isomers [37].

Although the manufacture and use of PCB and organochlorinated pesticides is banned or considerably restricted, these persistent compounds continue to be found even today among the pollutants contaminating aquatic environments all over the world [39-42]. It was noted that substances responsible for the activation of biochemical markers were present in all the locations monitored. The results of chemical monitoring also showed that locations with the highest values of biochemical markers were also those with the highest xenobiotic contaminations.

\section{Conclusion}

Analyses of biochemical markers of contamination and of chemical analyses of indicator fish showed that of the tributaries studied the ones that most contaminate the Elbe are the Jizera, Vltava, Ohře and Bílina. In most cases, elevated biomarker values were found together with elevated levels of the pollutants monitored. On the basis of concentrations of xenogenous substances found, these tributaries should not, however, be generally considered the main sources of industrial contamination of the River Elbe because the most important contamination sources are along the river Elbe itself.

\section{Acknowledgements}

This research was supported by the Ministry of the Environment of the Czech Republic SP/2e7/229/07 and by the Ministry of Education, Youth and Sports of the Czech Republic (MSM 621 5712402 and MSM 600766 5809).

\section{References}

1. Payne, J.F.; Fancey, L.L.; Rahimtula, A.D.; Porter, E.L. Review and perspective on the use of mixed-function oxygenase enzymes in biological monitoring. Comp. Biochem. Physiol. Pt C 1987, 86, 233-245. 
2. Adams, M.S.; Ballin, U.; Gaumert, T.; Hale, B.W.; Kausch, H.; Kruse, R. Monitoring selected indicators of ecological change in the Elbe River since the fall of the Iron Curtain. Environ. Conserv. 2001, 28, 333-344.

3. Hecker, M.; Sanderson, J.T.; Karbe, L. Suppression of aromatase activity in populations of bream (Abramis brama) from the River Elbe, Germany. Chemosphere 2007, 66, 542-552.

4. Randak, T.; Zlabek, V.; Kolarova, J.; Svobodova, Z.; Hajslova, J.; Siroka, Z.; Janska, M.; Pulkrabova, J.; Cajka, T.; Jarkovsky, J. Biomarkers detected in chub (Leuciscus cephalus L.) to evaluate contamination of the Elbe and Vltava Rivers, Czech Republic. B. Environ. Contam. Tox. 2006, 76, 233-241.

5. Siroka, Z.; Krijt, J.; Randak, T.; Svobodova, Z.; Peskova, G.; Fuksa, J.; Hajslova, J.; Jarkovsky, J.; Janska, M. Organic pollutant contamination of the River Elbe as assessed by biochemical markers. Acta Vet. BRNO 2005, 74, 293-303.

6. Stachel, B.; Ehrhorn, U.; Heemken, O.P.; Lepom, P.; Reincke, H.; Sawal, G.; Theobald, N. Xenoestrogens in the River Elbe and its tributaries. Environ. Pollut. 2003, 124, 497-507.

7. Zlabek, V.; Svobodova, Z.; Randak, T.; Valentova, O. Mercury content in the muscle of fish from the Elbe River and its tributaries. Czech J. Anim. Sci. 2005, 50, 528-534.

8. Jung, D.K.J.; Klaus, T.; Fent, K. Cytochrome P450 induction by nitrated polycyclic aromatic hydrocarbons, azaarenes, and binary mixtures in fish hepatoma cell line PLHC-1. Environ. Toxicol. Chem. 2001, 20, 149-159.

9. van der Oost, R.; Beyer, J.; Vermeulen, N.P.E. Fish bioaccumulation and biomarkers in environmental risk assessment: a review. Environ. Toxicol. Pharm. 2003, 13, 57-149.

10. White, R.D.; Shea, D.; Stegeman, J.J. Metabolism of the aryl hydrocarbon receptor agonist 3,3',4,4'tetrachlorobiphenyl by the marine fish scup (Stenotomus chrysops) in vivo and in vitro. Drug Metab. Dispos. 1997, 25, 564-572.

11. Malins, D.C.; McCain, B.B.; Brown, D.W.; Chan, S.L.; Myers, M.S.; Landahl, J.T.; Prohaska, P.G.; Friedman, A.J.; Rhodes, L.D.; Burrows, D.G.; Gronlund, W.D.; Hodgins, H.O. Chemicalpollutants in sediments and diseases of bottom-dwelling fish in Puget Sound, Washington. Environ. Sci. Technol. 1984, 18, 705-713.

12. Anzenbacherova, E.; Anzenbacher, P. Cytochromy P450 a metabolismus xenobiotik. Bull. Ceske Spol. Biochem. Mol. Biol. 1999, 1, 4-33.

13. Flammarion, P.; Devaux, A.; Nehls, S.; Migeon, B.; Noury, P.; Garric J. Multibiomarker responses in fish from the Moselle River (France). Ecotox. Environ. Safe. 2002, 51, 145-153.

14. Koehler, H.R.; Sandu, C.; Scheil, V.; Nagy-Petrica, E.M.; Segner, H.; Telcean, I.; Stan, G.; Triebskorn, R. Monitoring pollution in River Mures, Romania, Part III: biochemical effect markers in fish and integrative reflection. Environ. Monit. Assess. 2007, 127, 47-54.

15. Lowry, O.H.; Rosebrough, N.J.; Farr, A.L.; Randall, R.J. Protein measurement with the Folin phenol reagent. J. Biol. Chem. 1951, 193, 265-275.

16. Hajslova, J.; Schoula, R.; Holadova, K.; Poustka, J. Analysis of PCBs in biotic matrices by 2dimensional GC-ECD. Int. J. Environ. An. Ch. 1995, 60, 163-173.

17. Goksoyr, A.; Forlin, L. The cytochrome P-450 system in fish, aquatic toxicology and environmental monitoring. Aquat. Toxicol. 1992, 22, 287-311. 
18. Mayon, N.; Bertrand, A.; Leroy, D.; Malbrouck, C.; Mandiki, S.N.M.; Silvestre, F.; Goffart, A.; Thome, J.P.; Kestemont, P. Multiscale approach of fish responses to different types of environmental contaminations: A case study. Sci. Total Environ. 2006, 367, 715-731.

19. Al-Arabi, S.A.M.; Adolfsson-Erici, M.; Waagbo, R.; Ali, M.S.; Goksoyr, A. Contaminant accumulation and biomarker responses in caged fish exposed to effluents from anthropogenic sources in the Karnaphuly River, Bangladesh. Environ. Toxicol. Chem. 2005, 24, 1968-1978.

20. Behrens, A.; Segner, H. Cytochrome P4501A induction in brown trout exposed to small streams of an urbanised area: results of a five-year-study. Environ. Pollut. 2005, 136, 231-242.

21. Broeg, K.; Zander, S.; Diamant, A.; Korting, W.; Kruner, G.; Paperna, I.; von Westernhagen, $\mathrm{H}$. The use of fish metabolic, pathological and parasitological indices in pollution monitoring 1. North Sea. Helgoland Mar. Res. 1999, 53, 171-194.

22. Jedamskigrymlas, J.; Kammann, U.; Tempelmann, A.; Karbe, L.; Siebers, D. Biochemical responses and environmental contaminants in breams (Abramis-brama L) caught in the River Elbe. Ecotox. Environ. Safe. 1995, 31, 49-56.

23. Jedamskigrymlas, J.; Lange, U.; Siebers, D.; Karbe, L. Induction of the hepatic biotransformation system of golden ide [Leuciscus-idus (L)] after exposure in the River Elbe. Ecotox. Environ. Safe. 1994, 28, 35-42.

24. Heinisch, E.; Kettrup, A.; Bergheim, W.; Holoubek, I.; Wenzel, S. PCB in aquatic ecosystems of the river Elbe and Berlin waters - Source oriented monitoring. Fresen. Environ. Bull. 2003, 12, 103-110.

25. Breivik, K.; Sweetman, A.; Pacyna, J.M.; Jones, K.C. Towards a global historical emission inventory for selected PCB congeners - A mass balance approach. 3. An update. Sci. Total Environ. 2007, 377, 296-307.

26. Kitamura, S.; Yoshida, M.; Sugihara, K.; Ohta, S. Reductive dechlorination of p,p '-DDT mediated by hemoproteins in the hepatopancreas and blood of goldfish, Carassius auratus. J. Health Sci. 1999, 45, 217-221.

27. Ackermann, G.E.; Brombacher, E.; Fent, K. Development of a fish reporter gene system for the assessment of estrogenic compounds and sewage treatment plant effluents. Environ. Toxicol. Chem. 2002, 21, 1864-1875.

28. Toppari, J.; Larsen, J.C.; Christiansen, P.; Giwercman, A.; Grandjean, P.; Guillette, L.J.; Jegou, B.; Jensen, T.K.; Jouannet, P.; Keiding, N.; Leffers, H.; McLachlan, J.A.; Meyer, O.; Muller, J.; RajpertDeMeyts, E.; Scheike, T.; Sharpe, R.; Sumpter, J.; Skakkebaek, N.E. Male reproductive health and environmental xenoestrogens. Environ. Health Perspect. 1996, 104, 741-803.

29. Leanos-Castaneda, O.; Van Der Kraak, G.; Rodriguez-Canul, R.; Gold, G. Endocrine disruption mechanism of o,p'-DDT in mature male tilapia (Oreochromis niloticus). Toxicol. Appl. Pharm. 2007, 221, 158-167.

30. Metcalfe, T.L.; Metcalfe, C.D.; Kiparissis, Y.; Niimi, A.J.; Foran, C.M.; Benson, W.H. Gonadal development and endocrine responses in Japanese medaka (Oryzias latipes) exposed to o,p '-DDT in water or through maternal transfer. Environ. Toxicol. Chem. 2000, 19, 18931900. 
31. Nims, R.W.; Lubet, R.A.; Fox, S.D.; Jones, C.R.; Thomas, P.E.; Reddy, A.B.; Kocarek, T.A. Comparative pharmacodynamics of CYP2B induction by DDT, DDE, and DDD in male rat liver and cultured rat hepatocytes. J. Toxicol. Env. Health Pt A 1998, 53, 455-477.

32. Gonzalez, A.; Piferrer, F. Aromatase activity in the European sea bass (Dicentrarchus labrax L.) brain. Distribution and changes in relation to age, sex, and the annual reproductive cycle. Gen. Comp. Endocr. 2003, 132, 223-230.

33. Bailey, R.E. Global hexachlorobenzene emissions. Chemosphere 2001, 43, 167-182.

34. Heinisch, E.; Kettrup, A.; Bergheim, W.; Martens, D.; Wenzel, S. Persistent chlorinated hydrocarbons (PCHC), source-oriented monitoring in aquatic media. 4. The chlorobenzenes. Fresen. Environ. Bull. 2006, 15, 148-169.

35. Luckas, B.; Oehme, M. Characteristic contamination levels for polychlorinated hydrocarbons, dibenzofurans and dibenzo-para-dioxins in bream (Abramis brama) from the River Elbe. Chemosphere 1990, 21, 79-89.

36. Oxynos, K.; Schramm, K.W.; Marth, P.; Schmitzer, J. Chlorinated hydrocarbons (CHC) and PCDD/F-levels in sediments and breams (Abramis-brama) from the River Elbe (A contribution to the German Environmental Specimen Banking). Fresenius J. Anal. Chem. 1995, 353, 98100.

37. Marth, P.; Oxynos, K.; Schmitzer, J.; Schramm, K.W.; Kettrup, A. Levels of chlorinated hydrocarbons (CHC) in breams (Abramis brama) from the River Elbe (A contribution to the Federal Environmental Specimen Bank). Chemosphere 1997, 34, 2183-2192.

38. Bester, K.; Biselli, S.; Ellerichmann, T.; Huhnerfuss, H.; Moller, K.; Rimkus, G.; Wolf, M. Chlorostyrenes in fish and sediment samples from the River Elbe. Chemosphere 1998, 37, 2459-2471.

39. Deboer, J.; Vandervalk, F.; Kerkhoff, M.A.T.; Hagel, P.; Brinkman, U.A.T. 8-year study on the elimination of PCBs and other organochlorine compounds from eel (Anguilla-anguilla) under natural conditions. Environ. Sci. Technol. 1994, 28, 2242-2248.

40. Ferrante, M.C.; Cirillo, T.; Naso, B.; Clausi, M.T.; Lucisano, A.; Cocchieri, R.A. Polychlorinated biphenyls and organochlorine pesticides in seafood from the Gulf of Naples (Italy). J. Food Protect. 2007, 70, 706-715.

41. Vorkamp, K.; Riget, F.; Glasius, M.; Pecseli, M.; Lebeuf, M.; Muir, D. Chlorobenzenes, chlorinated pesticides, coplanar chlorobiphenyls and other organochlorine compounds in Greenland biota. Sci. Total Environ. 2004, 331, 157-175.

42. Yang, N.Q.; Matsuda, M.; Kawano, M.; Wakimoto, T. PCBs and organochlorine pesticides (OCPs) in edible fish and shellfish from China. Chemosphere 2006, 63, 1342-1352.

(C) 2007 by MDPI (http://www.mdpi.org). Reproduction is permitted for noncommercial purposes. 